\title{
Exploring The Use of Translation as a Strategy to Learn English
}

\author{
Ajeng Dini Arfianti ${ }^{1}$, Utami Widiati ${ }^{1}$ \\ ${ }^{1}$ Pendidikan Bahasa Inggris-Universitas Negeri Malang
}

\begin{tabular}{l} 
INFO ARTIKEL \\
\hline Riwayat Artikel: \\
Diterima: $31-12-2019$ \\
Disetujui: $13-10-2020$ \\
\hline
\end{tabular}

Keywords:

translation;

english learning;

learning strategy;

terjemahan;

belajar bahasa Inggris;

strategi pembelajaran

\begin{abstract}
ABSTRAK
Abstract: This study primarily wanted to explore students' views and how they employ translation-related strategies to learn English. Five students from the accounting department, Universitas Negeri Malang participate in this qualitative case study. The findings showed that students consider translation has a positive contribution to their English learning. They also mentioned learning activities by using translation that can be categorized into several learning strategies. It is expected that the results of the study can raise awareness and exercise cautious use of translation as an effective learning strategy in English for the benefits of the students.
\end{abstract}

\begin{abstract}
Abstrak: Penelitian ini ingin mengeksplorasi pandangan siswa dan bagaimana mereka menggunakan strategi terkait terjemahan untuk belajar bahasa Inggris. Lima mahasiswa dari jurusan akuntansi, Universitas Negeri Malang berpartisipasi di studi kasus kualitatif ini. Hasil wawancara menunjukkan bahwa siswa menganggap terjemahan memiliki kontribusi positif untuk pembelajaran bahasa Inggris. Mereka juga menyebutkan beberapa kegiatan belajar yang terkait dengan penggunaan terjemahan yang dapat dikategorikan ke dalam beberapa strategi pembelajaran. Diharapkan hasil penelitian ini dapat meningkatkan kesadaran dan melatih penggunaan terjemahan secara hati-hati sebagai strategi pembelajaran bahasa Inggris yang efektif untuk kepentingan siswa.
\end{abstract}

\section{Alamat Korespondensi:}

Ajeng Dini Arfianti

Pendidikan Bahasa Inggris

Universitas Negeri Malang

Jalan Semarang 5 Malang

E-mail: ajengdinia@gmail.com

The involvement of translation in the language learning process has been neglected for decades even though its utilisation may assist learners in mastering a new language. Many language researchers and teachers have considered translation as an inappropriate association in a classroom situation, and it is considered as the major cause of students' problem in learning a new language (Dulay, Burt, \& Krashen, 1982). The reason is that teaching and learning of target language like English are suggested to only be focused on the target language, avoiding involvement of learners' native languages. Many studies indicate that promoting as much as exposure to English while avoiding any use of the first language is the key to succeed English acquisition (Almoayidi, 2018). Such belief may be caused by concerns about translation promoting impractical and unnecessary language contents (e.g., memorizing unneeded vocabulary and grammar) which may hinder learners to fully embrace the target language and cause cognitive overload (Liu \& Shi, 2007).

However, language learners naturally have the inclination to understand something the unknown like foreign languages by relating them first to the known like their native languages (Cook, 2007). For instance, adult learners tend to depend on their native language as their first tool to learn a new language. Moreover, beginner or lower-level students can learn the language in a more comfortable and safe way by using their first language (Pan \& Pan, 2012; Mutlu, Bayram, and Demirbüken, 2015; Putrawan, 2019). Dulay et al. (1982) characterize such habit as an adults' cognitive factor in the form of conscious language learning. In this case, adults often learn to construct a new language by using their first language patterns and combine them with foreign language vocabulary words that they know. This idea aligns with Hidayati's study (2012) which concludes using Bahasa during English lesson for university students is beneficial not only to assist grammar and vocabulary learning but also to provide students with encouragements and feedbacks. In her study, she also emphasizes on limiting the use of Bahasa accordingly to keep the quality of the English lesson. Furthermore, Harmer (2007) believes that translation is a natural process of learning a foreign language when students, especially in the beginner level like many Indonesian adults, translate foreign language materials into their first language. This idea is supported by the emerging recognition of translation as a learning strategy from recent publications (Aktekin \& Gliniecki, 2015; Al-Musawi, 2014; Asgarian \& Musayeva Vefal1, 2015; Bagheri \& Fazel, 2011; Calis \& Dikilitas, 2012; Dagilienè, 2012; Kuluşaklı, Boynukara, \& Genç, 2018; Liao, 2006). 
Understanding the term "translation" is essential in this study to avoid any misunderstanding. Al-Musawi (2014) suggests translation is a popular learning method used 'to transmit the appropriate meaning of a word or a sentence linguistically, semantically, and pragmatically' by foreign language learners. In this study, translation is focused on its involvement as a language learning skill in which students change words, sentences, texts, and speeches in English to Bahasa, or the other way around (i.e., in both written and oral form). Unfortunately, translation in the educational contexts like Indonesia is mainly known for its grammatical focus which leads towards the negative perceptions of translation, especially as a learning strategy in English education.

Furthermore, learners' use of translation as a learning strategy may be classified into six categories, namely cognitive, affective, social, compensatory, memory, and metacognitive strategies (Al-Musawi, 2014; Liao, 2002; Mollaei, Taghinezhad, \& Sadighi, 2017). Translation is often used as a cognitive strategy which involves processing, receiving, and transferring foreign language material based on students' first language. Through this strategy, students can analyse language inputs like new vocabularies to generate new understanding in English. For instance, students can translate difficult English words into Bahasa Indonesia to help them understand an English text. In affective strategy, translation may reduce students' anxiety in learning a new language. While facing English as a foreign language, students with low proficiency level may use translation to lower the risk in making a false understanding of written or oral languages. This possibility also helps students encourage themselves in continuing their learning despite having few understandings towards English vocabularies and grammatical structures. For example, doing translation through an online dictionary like Google Translate can assist a low achiever student in reducing anxiety while independently learning a rather difficult text.

Furthermore, translation may be used as a social strategy when students collaborate in solving English tasks through translation. According to Mollaei et al. (2017) this strategy includes situations where students are actively asking questions to their friends about the meaning of English words or sentences. The question usually comes from low-proficiency students, and it seeks for clarification, correction, or confirmation about their understanding of the high-proficiency students. Also, students normally utilize translation as a compensatory strategy when they produce English texts (Liao, 2006). In this case, students compose and organise ideas in Bahasa to compensate for their lack of English proficiency and then translating the ideas to English. In addition, the compensatory strategy also happens when students try to translate a text by guessing unknown words or sentences from linguistics clues available in the text. Translation may serve as a memory strategy when students create associations between first language translation and target language texts. For instance, students memorize the meaning of new English vocabulary by remembering the meaning in Bahasa Indonesia. Lastly, metacognitive strategy is commonly used by students with high proficiency. Students utilise translation to evaluate or review their English. For instance, while creating a text or speech in English, students can try to translate their text to Bahasa to make sure that they have structures or part of speeches in the correct arrangement.

The revival of translation ignites numerous studies supporting its role in foreign language learning, especially in higher education level. Firstly, Fernández-Guerra (2014), in her study, supports the use of translation in foreign language classrooms. She indicates that translation has positive effects and can be a valuable skill in classroom activities. For instance, translation can motivate and facilitate students in comparing the linguistic systems of both English and Bahasa Indonesia. Secondly, Dagiliene (2012) and Al-Musawi (2014) elucidates that translation can be utilized as a strategy for language learning for university students. They approve the idea that translation is an effective tool to develop learners' communication competence since it encourages learners' communication and understanding by involving interaction and cooperation among them. Other empirical studies supporting translation as a learning strategy can also be found in Liao (2002), Bagheri \& Fazel (2011), Asgarian \& Musayeva Vefalı (2015).

The results of previous studies show that most second and foreign language learners (i.e., students in higher education levels) tend to have a positive attitude on the use of translation in their English learning, especially if they have low proficiency. For example, a study conducted by Al-Musawi (2014) reveals that the use of translation can help less proficient Arab university students to learn English vocabulary and reduce their anxiety when learning a foreign language. However, none of those previous studies conducted in in-depth qualitative research on how adult students in higher education level employ translation to help them learn English. Therefore, in this study, the researcher aims to conduct a qualitative case study research in Indonesian EFL higher education context like English for Special Purpose Program (ESP). She believes that investigating how the adult students employ translation-related learning strategies to learn English is essential to provide more insights on the development of translation as a learning method in recent years, especially considering the lack of in-depth research concerning translation in the higher education settings in Indonesia.

\section{METHOD}

A qualitative case study was employed as the research methodology. This methodology is chosen because it emphasizes on exploring and describing a case to understand a contemporary phenomenon within a real-life context (Yin, 2003; Latief, 2012). Such definition and emphasis are in line with the goal of the study which aims to explore and describe an issue about translation use among Indonesian higher education students, especially in this era where the communicative approach to English learning and digital technology become the norm. Related to the data collection, the methodology in this research is categorized as 
exemplifying single-case design. Exemplifying design enabled the researcher to describe individual experiences and social processes based on a theory and use them as an example of a broader context (Bryman, 2016; Yin, 2018).

In this case, the researcher gathered the data through interviews to answer the research questions. Then, the data analysis was conducted to provide a better understanding concerning ESP students' use of translation as their learning strategy through theoretical analysis. Considering the small scope of the study, the researcher treated the result of the study more as an example instead of a representation of the context or population. This idea aligned with the use of single-case design where the researcher focused on a single case for the study based on geographical context (i.e., one faculty in a university). This single-case design allowed the researcher to limit the focus and contribute useful information to the existing knowledge for further investigations to the broader context or entire filed (Yin, 2018). As a result, the case study entailed a detailed and in-depth analysis of ESP students' views and learning strategies about translation in English learning generated from a selected university in Indonesia. The findings of this research were not generalized since the researcher only aims to provide current insights regarding the use of translation as a learning strategy to learn English limitedly in an Indonesian higher education setting.

In consideration of the scale of the research, the researcher involved five Accounting department students of Universitas Negeri Malang. They were chosen through a snowball sampling technique adapted from procedures proposed by Best \& Kahn (2006) and Bryman (2016). The researcher administered an online questionnaire through social media WhatsApp to find the final five participants. The questionnaire asked about students' current English proficiency (i.e., TOEFL scores administered by the university), their learning habits, and whether or not they often employ translation as learning strategies. The five participants chosen were those who had low or intermediate proficiency (i.e., two students with low proficiency, one student with preintermediate proficiency, and two students with intermediate proficiency), often learnt English outside classrooms and regularly used translation during English learning. The researcher invited those students in a series of interviews to investigate how they felt about translation and their translation-related strategies to improve their English. Below is a table containing the selected participants and their characteristics.

Table 1. Characteristics of the Participants

\begin{tabular}{ccccc}
\hline No. & Name & TOEFL score (university) & Age & Semester \\
\hline 1 & Tomi & 400 & 20 & $3^{\text {rd }}$ \\
2 & Jenni & 387 & 19 & $3^{\text {rd }}$ \\
3 & Ryan & 490 & 19 & $3^{\text {rd }}$ \\
4 & Ari & 540 & 19 & $3^{\text {rd }}$ \\
5 & Yulia & 420 & 20 & $3^{\text {rd }}$ \\
\hline
\end{tabular}

\section{RESULTS AND DISCUSSION}

\section{Students' views on the use of translation as a strategy to learn English}

The positive perception of translation from the students suggested that translation is an efficient strategy to learn a new language. The participants especially those low achiever students believed that they need translation because it is a quick and simple way to help them understand English material, such as by using Google Translate to translate difficult words from an English text. This is in line with the previous studies written by Putrawan (2019) and Mutlu et al (2015) who also supported the idea that low achiever students employ translation to learn a second language because translation eventually enables them to participate in the classroom activity. In addition, it can improve their reading skill by enhancing their comprehension of a text and enriching their vocabulary (Aktekin \& Gliniecki, 2015; Liao, 2006).

Furthermore, both high and low achiever students agree that translation can help them study efficiently inside and outside the classroom. Based on the findings, high achiever students mostly use translation outside classroom activity. For instance, Ryan and Ari mentioned that they improve their English skills by watching movies or videos on Youtube. In other words, they exposed themselves to English material and sometimes tried to find the Indonesian translation of English words they did not understand. This kind of activity also proves that the use of translation cannot be avoided especially by university students who seek to improve their English skill not only by attending classes but also practicing English outside the classroom. This is also in line with the study written by Kuluşaklı et al. (2018) who mentioned that foreign language learners developed their understanding on English content by watching TV or movies in the target language inside or outside the classroom.

Additionally, the students see translation as a natural and inseparable part of English learning. As stated by Dulay et al. (1982), Cook, (2007), and Pan \& Pan (2012), learning a new language by using students' first language has become a habit and it is a natural phenomenon. Students spontaneously will employ translation with or without their teacher's permission because it is their useful resource to cover the lack of knowledge in foreign language learning. Moreover, when they cannot utter or produce the correct English sentence, they will naturally relay on their first language by comparing its closest equivalent to the target language material (Asgarian \& Musayeva Vefal1, 2015). This also proves the importance and positive role of the first language that cannot be avoided (Kuluşaklı et al., 2018). 
On the other hand, the participants, especially high proficiency students, expressed less positive perception towards translation, especially when it is used as the main activity. For instance, Ryan and Ari mentioned that their teacher often asked them to translate English texts in every meeting. The use of translation as the main activity will be closely associated with the traditional Grammar Translation Method in which teacher takes full control of the process of teaching-learning activity by analyzing the target language sentences using translation (Vermes, 2010). Even though this kind of activity encourages students to enhance their reading understanding to the English texts (Usadiati, 2010), it was not well-received by the students since their classroom activity is confined only to reading and writing activities. This is in line with Kuluşaklı et al. (2018) research which mentioned that students employ their first language to understand a text and plan what they want to write in the foreign language.

The use of translation may encourage students more to depend on translation during English learning. The dependency is considered as negative because students usually treat translation, in this case, online translation, as both shortcut and main strategy in doing English tasks. The online translation is used to do the majority of the reading and writing processes considering some of the participants translate almost all the English texts (i.e., for reading) and outlines in Bahasa to English (i.e., for writing). Such method diminishes the essence of learning English. Meanwhile, Chandra \& Yuyun (2018) suggests that online translation is utilized as a supporting tool in learning so that it does not give a negative influence on learning. By only using translation as a complementary or supporting tool, students may yield more reliable English scores in reading or writing activities. In this study, the low proficiency students have the tendency to use translation to do all the work during learning activities, and this may mask their real competences or even slow down their learning.

Lastly, the study implies that translation may promote inaccurate learning for students. Even though translation is suggested to not worsen the writing performance (Chandra \& Yuyun, 2018), reckless utilization of translation can produce incorrect results which hinder students' learning. Based on the findings, more than half of the participants use online translation to translate sentences or paragraph. This condition is troubling as they may not fully understand the level of accuracy of the translation. Medvedev (2016) argues that translation is an inseparable part of a bilingual classroom, but the utilization should be constantly monitored by the teacher to avoid students being lost in the translation, especially while using online translation. According to the participants, their lecturer took the shortcut and mostly forbade the use of translation in the classroom to avoid such drawback. However, despite the ban, the participants stated that they needed translation during classes due to the lack of proficiency. Thus, this condition indicates that there has not been a proper solution to solve this drawback of translation.

\section{The use of translation as a strategy to learn English}

Based on the findings, the participants mentioned various activities involving translation, especially during English learning. Firstly, during English learning, students mention various activities involving translation that can be categorized into the cognitive strategy. Based on the findings, watching movies or videos using Indonesian subtitle, translating words or sentences from English texts using online dictionary are activities that involve processing foreign language material into students' first language in order to improve their understanding to the content. This is in line with Liao (2002) who argued that translation can be used as a cognitive strategy when students compared and analysed first and foreign languages to determine whether their understanding was accurate or not. This strategy is beneficial especially for students who want to enrich their English vocabulary not only inside but also outside the classroom.

Students employ translation as memory strategy when they try to memorize English words or phrases. The findings show that students' ability to remember the meaning of English vocabulary depends on how frequent they read on English sentences or hear the words from their teacher or videos they watch. High achiever students can memorize English vocabulary without Indonesian translation if they are quite familiar with the words or sentences, yet low achiever students use Indonesian translation to memorize English words or phrases. The result is consistent with studies by Liao (2006) and Mollaei et al. (2017), who mentioned that learners can memorize the meaning of English vocabulary and phrases by using translation. In addition, Calis \& Dikilitas's study (2012) revealed that translation is a valuable tool to memorize the target language's vocabulary.

In terms of compensatory strategy, the use of translation can cover the participants' inadequate knowledge, especially in English writing. The findings show that the participants did some measures before they can write the complete English text. Some of them are brainstorming the topic and arranging sentences using bahasa Indonesia. This result is also consistent with Bagheri \& Fazel's study (2011), which revealed that translation can help language learners in developing and expressing ideas. In addition, Aktekin \& Gliniecki (2015) further suggested that initially, learners would think in their first language before they start to write.

Translation as an affective strategy has a significant role in controlling students' emotion during English learning. Based on the findings, the participants, especially low achiever students, argued that they feel motivated and comfortable to learn English by using translation. High achiever students considered that translation could play a role in helping them explaining the difficult English words to their friends without getting anxious that their explanation would be wrong. This result is in line with Al-Musawi (2014) and Mutlu et al. (2015) explored that the use of translation can reduce learners' anxiety and pressure in learning foreign language especially when executing the assignments from their teacher.

In addition, translation as a social strategy enables students to learn English collaboratively with their peers. This strategy emphasizes more on the interaction among students as they learn by sharing their knowledge of the target language, especially English. Based on the findings, the participants mentioned activities such as asking their peers to explain the English material and working together to find the English meaning and fulfil their English assignments. Karimian \& Talebinejad (2013) and Al-Musawi 
(2014) pointed out that collaborative activities among students using translation encourage them to learn a new language in a friendly environment both inside and outside the classroom. Furthermore, translation can help students to create more independent learning in which they are able to evaluate their works. According to Li (2013), metacognitive awareness and its implementation are essential for students to assist them in understanding their learning capability, pace, and style to form an effective learning process. In this study, the students were observed to use translation as a metacognitive strategy with a different level of awareness.

The students with higher proficiency are fully aware that translation can help them evaluate and improve their vocabulary and grammar in writing skill. On the other hand, the students with lower proficiency see translation as a tool to check their grammar only without realizing its potential in evaluating their writings in other aspects. Li's study (2013) shows that the metacognitive strategy can promote more interesting learning activities as students can control their learning. Aligns with Li's study, the findings of this study indicate that the students with higher awareness towards translation metacognitive strategy have more control over their learning and higher satisfaction level on the results of the learning.

Meanwhile, the students with lower awareness tended to be easily satisfied with the vocabularies in their writings even though they had not explored fully the use of translation as an evaluation tool for vocabulary selection. This might cause an issue in their learning, as Jamaris (2013) suggests that many Indonesian students use translation as the main tool for vocabulary learning. The unawareness of translation's metacognitive benefits in vocabulary learning may promote negative English learning. For example, when students only focused on using translation (i.e., translation applications like Google Translate) as grammar checking tools, they may ignore wrong selections of vocabulary and learn them as if they are correct. Such circumstance is believed to lead towards prolonged English learning in the long-term (Jamaris, 2013).

\section{CONCLUSION}

The use of translation as a strategy previously has been deemed an inappropriate tool to help students learning a new language. Its role in foreign language learning can cause debate among language researchers and teachers because some of them agree, and the others disagree about its involvement during the learning process. Nevertheless, recent studies (Al-Musawi, 2014; Asgarian \& Musayeva Vefal1, 2015; Dagilienė, 2012; Liao, 2006; Mollaei et al., 2017; Pan \& Pan, 2012; Putrawan, 2019) reintroduced translation as students' strategy that can help them learn a foreign language. This study primarily wanted to explore students' views on translation as a language strategy and how they employ translation-related strategies to learn English.

The results of the interview showed that translation has a significant role in the participants' English learning process. They see translation as an efficient strategy and as a natural part of their foreign language learning. It is reflected in statements such as translation allows them to understand English material in a quick way and its role in covering students' lack of knowledge. Besides the positive views on translation, the participants mentioned that translation could also pose as a negative option to learn a new language. Some of them believe its involvement can cause negative dependency and bad learning habit. Furthermore, the participants mentioned several activities related to the use of translation as a learning strategy. They believe its role can help them understand difficult words, lower their anxiety towards English learning, develop English texts, enrich their vocabulary, assist their peers in exercising English tasks, and evaluate their works. These activities specifically are students' use of translation as cognitive, affective, compensatory, memory, social, and metacognitive strategy.

Overall, this study is categorized exemplifying single-case design and focused on describing the participants' experiences on using translation as an English learning strategy. The results have revealed both positive and negative views on the use of translation and how its employment during English learning. Low achiever students show a more favourable response to translation as a learning strategy compared to the other students. They pointed out that translation is a valuable tool in assisting them in learning a foreign language, especially English. On the other hand, high achiever students believe that translation can also contribute to the English learning, but its involvement should be lessened to avoid dependency in the future since its nature is only beneficial in some aspects such as adding new vocabulary and improving their understanding about English contents. With regard to the findings of the study, it is expected that translation can bring useful information, especially concerning its involvement during foreign language learning. Students with low proficiency still consider translation as a valuable and useful strategy to learn English. Meanwhile, students with high proficiency showed moderate use of translation as they do not want to rely much on it. In addition, as suggested by Ali (2012), teachers should not totally ban the use of translation of their students especially in higher education level because there are some students whose proficiency level is still considered low and they need translation to compensate their lack of knowledge. Moreover, teachers may employ translation during teaching and learning process as a medium to check the students' understanding instead of as the main classroom activity.

Since this study is only focused on exploring students' views and how they employ it to help them learn English, there are several aspects that can be investigated more in future studies. Firstly, it is possible to add teachers' views on students' use of translation since there might be different understanding on how much translation should be involved during foreign language learning. Observation of how students employ translation during English learning is also recommended to intensify the depth of the data. Additionally, quantitative research may complement this present study by increasing the number of participants and if it is possible from different faculty to provide more reliable data on students' use of translation especially in higher education level in Indonesia. 


\section{REFERENCES}

Aktekin, N. Ç., \& Gliniecki, A. U. (2015). ELT Students’ Beliefs about and Strategy Use of Translation. International Online Journal of Education and Teaching (IOJET), 2(1), 12-24.

Ali, S. (2012). Integrating Translation into Task-Based Activities - A New Direction for ESL Teachers. Language in India, 12, 429-438.

Almoayidi, K. A. (2018). The Effectiveness of Using L1 in Second Language Classrooms: A Controversial Issue. Theory and Practice in Language Studies, 8(4), 375-379. https://doi.org/10.17507/tpls.0804.02

Al-Musawi, N. M. (2014). Strategic Use of Translation in Learning English as a Foreign Language (EFL) among Bahrain University Students. Comprehensive Psychology, 3, 1-10. https://doi.org/10.2466/10.03.IT.3.4

Asgarian, A., \& Musayeva Vefalı, G. (2015). How do English Translation Majors use Translation Strategies? A Survey of the Iranian EFL Context. Journal of Multilingual and Multicultural Development, 36(3), 313-329. https://doi.org/10.1080/01434632.2014.921186

Bagheri, M. S., \& Fazel, I. (2011). EFL Learners Beliefs about Translation and its Use as a Strategy in Writing. The Reading Matrix, 11(3), 292-301.

Bryman, A. (2016). Social Research Methods (5th ed.). Oxford: Oxford University Press.

Calis, E., \& Dikilitas, K. (2012). The Use of Translation in EFL Classes as L2 Learning Practice. Procedia - Social and Behavioral Sciences, 46, 5079-5084. https://doi.org/10.1016/j.sbspro.2012.06.389

Chandra, Sylvi Octaviani, \& Yuyun, Ignasia. (2018). The Use of Google Translate in EFL Essay Writing. LLT Journal: A Journal on Language and Language Teaching, 21(2), 228-238. https://doi.org/doi.org/10.24071/llt.2018.210212

Cook, G. (2007). A Thing of the Future: Translation in Language Learning. International Journal of Applied Linguistics, 17(3), 396-401. https://doi.org/10.1111/j.1473-4192.2007.00160.x

Dagilienè, I. (2012). Translation as a Learning Method in English Language Teaching. Studies About Languages, O(21), 124129. https://doi.org/10.5755/j01.sal.0.21.1469

Fernández-Guerra, A. (2014). The Usefulness of Translation in Foreign Language Learning:. International Journal of English Language \& Translation Studies, 2(1), 153-170.

Harmer, J. (2007). The Practice of English Language Teaching. Harlow: Pearson Education Limited.

Hidayati, I. N. (2012). Evaluating the Role of L1 in Teaching Receptive Skills and Grammar in EFL Classes. Indonesian Journal of Applied Linguistics, 1(2), 17-32. https://doi.org/10.17509/ijal.v1i2.82

Jamaris. (2013). Metacognitive Strategy for Vocabulary Learning. Ta'dib, 16(2), 187-199.

Karimian, Z., \& Talebinejad, M. R. (2013). Students' Use of Translation as a Learning Strategy in EFL Classroom. Journal of Language Teaching and Research, 4(3), 605-610.

Kuluşaklı, E., Boynukara, E., \& Genç, G. (2018). EFL Learners' Use of Translation as a Learning Strategy. ELT Research Journal, 7(4), 175-188.

Latief, M. A. (2012). Research Methods on Language Learning: An Introduction. Malang: UM Press.

Li, W. (2013). A Study of Metacognitive Awareness of Non-English Majors in L2 Listening. Journal of Language Teaching and Research, 4(3), 504-510. https://doi.org/10.4304/jltr.4.3.504-510

Liao, P. (2002). Taiwanese Students' Belief about Translation and Their Use of Translation as a Strategy to Learn English. Unpublished PhD thesis. Austin, USA: The University of Texas at Austin.

Liao, P. (2006). EFL Learners' Beliefs about and Strategy Use of Translation in English Learning. RELC Journal, 37(2), 191215. https://doi.org/10.1177/0033688206067428

Liu, Q., \& Shi, J. (2007). An Analysis of Language Teaching Approaches and Methods-Effectiveness and Weakness. USChina Education Review, 4(1), 69-71.

Medvedev, G. (2016). Google Translate in Teaching English. The Journal of Teaching English for Specific and Academic Purposes, 4(1), 181-193.

Mollaei, F., Taghinezhad, A., \& Sadighi, F. (2017). Teachers and Learners' Perceptions of Applying Translation as a Method, Strategy, or Technique in an Iranian EFL Setting. International Journal of Education and Literacy Studies, 5(2), 6773. https://doi.org/10.7575/aiac.ijels.v.5n.2p.67

Mutlu, G., Bayram, D., \& Demirbürken, B. (2015). Translation as a Learning Strategy of Turkish EFL Learners. International Journal on New Trends in Education and Their Implications, 236-245.

Pan, Y., \& Pan, Y. (2012). The Use of Translation in the EFL Classroom. Philippine ESL Journal, 9, 4-23.

Putrawan, G. E. (2019). The Role of First Language and Translation in EFL Learning: A Brief Literature Review. International Journal of Linguistics, Literature and Translation (IJLLT), 2(2), 150-154. https://doi.org/10.32996/ijllt.2019.2.2.23

Usadiati, W. (2010). Contribution of L1 in EFL Teaching. K@ta Lama, 11(2), 171-183.

Vermes, A. (2010). Translation in Foreign Language Teaching: A Brief Overview of Pros and Cons. Eger Journal of English Studies, X, 83-93.

Yin, R. K. (2018). Case Study Research and Applications: Design and Methods. Thousand Oaks: SAGE Publications Inc. 